\title{
Captopril reduces cardiac inflammatory markers in spontaneously hypertensive rats by inactivation of NF-kB
}

\author{
José L Miguel-Carrasco, Sonia Zambrano, Antonio J Blanca, Alfonso Mate and Carmen M Vázquez*
}

\begin{abstract}
Background: Captopril is an angiotensin-converting enzyme (ACE) inhibitor widely used in the treatment of arterial hypertension and cardiovascular diseases. Our objective was to study whether captopril is able to attenuate the cardiac inflammatory process associated with arterial hypertension.

Methods: Left ventricle mRNA expression and plasma levels of pro-inflammatory (interleukin-1 $\beta$ (IL-1 $\beta$ ) and IL-6) and anti-inflammatory (IL-10) cytokines, were measured in spontaneously hypertensive rats (SHR) and their control normotensive, Wistar-Kyoto (WKY) rats, with or without a 12-week treatment with captopril $(80 \mathrm{mg} / \mathrm{Kg} / \mathrm{day}$; $\mathrm{n}=$ six animals per group). To understand the mechanisms involved in the effect of captopril, mRNA expression of ACE, angiotensin II type I receptor (AT1R) and p22phox (a subunit of NADPH oxidase), as well as NF-kB activation and expression, were measured in the left ventricle of these animals.
\end{abstract}

Results: In SHR, the observed increases in blood pressures, heart rate, left ventricle relative weight, plasma levels and cardiac mRNA expression of IL-1 $\beta$ and IL-6, as well as the reductions in the plasma levels and in the cardiac mRNA expression of IL-10, were reversed after the treatment with captopril. Moreover, the mRNA expressions of ACE, AT1R and p22phox, which were enhanced in the left ventricle of SHR, were reduced to normal values after captopril treatment. Finally, SHR presented an elevated cardiac mRNA expression and activation of the transcription nuclear factor, NF-KB, accompanied by a reduced expression of its inhibitor, IKB; captopril administration corrected the observed changes in all these parameters.

Conclusion: These findings show that captopril decreases the inflammation process in the left ventricle of hypertensive rats and suggest that NF-kB-driven inflammatory reactivity might be responsible for this effect through an inactivation of NF-KB-dependent pro-inflammatory factors.

\section{Background}

The spontaneously hypertensive strain of the WistarKyoto rat, that is the spontaneously hypertensive rat (SHR), provides a useful experimental model that develops hypertension and is characterized by structural and functional changes in the heart [1]. The heart to body mass ratio or the relative weight of the left ventricle, useful indices of ventricular hypertrophy at the organ level, have been found by several authors to be elevated in SHR [2-4]. This cardiac hypertrophy is correlated with an inflammatory process, suggesting that inflammation

*Correspondence: vazquez@us.es

1 Departamento de Fisiología y Zoología, Facultad de Farmacia, Universidad de Sevilla, E-41012 Sevilla, Spain

Full list of author information is available at the end of the article could be a key event in cardiovascular complications in hypertensive animals $[5,6]$. We and other authors have shown an increase in the heart inflammatory process in SHR [7], in L-NAME-induced arterial hypertension [8], as well as in hypertension induced by angiotensin II or aldosterone $[9,10]$.

Angiotensin II (ANGII), the key effector of the reninangiotensin system (RAS), plays an important role in the regulation of blood pressure, and there is accumulating evidence to indicate that ANGII is also capable of inducing an inflammatory response in the cardiac tissue through the activation of the nuclear factor $\kappa B(N F-\kappa B)$ [11-13]. Recent studies have also described the role of interleukin-10 (IL-10) in ANGII-induced expression of 
pro-inflammatory cytokines and vascular dysfunction [14].

Angiotensin-converting enzyme (ACE) inhibitors have long been known to be effective in the reduction of blood pressure and in the regression of left ventricular hypertrophy both in humans with essential hypertension [15] and in different animal models of arterial hypertension, such as SHR [16] and NO-deficient hypertensive rats [17]. Moreover, the treatment with ACE inhibitors reversed the increase in the production of superoxide anions and the activation of NF-kB system, as well as the elevated expression of pro-inflammatory cytokines, in aortas of rat with reduced NO synthesis [18] and in a rabbit model of atherosclerosis [19]. Also, a reduction in the circulating levels of intercellular adhesion molecule-1 (ICAM-1) has been observed in hypertensive patients [20] and in human aortic endothelial cells [21] after the treatment with an ACE inhibitor.

Captopril is a widely used ACE inhibitor for treatment of arterial hypertension and cardiovascular diseases $[22,23]$. It has been shown to express immune regulating, antioxidant and anti-inflammatory properties [24]. Thus, captopril has been proved to be beneficial in experimental autoimmune encephalomyelitis [25], adriamycininduced nephropathy [26], arthritis [27] and experimental rat colitis [28]. Captopril suppresses the inflammation in endotoxin-induced uveitis in rats [29]; improves oxidative stress in the kidney of L-NAME-treated rats [30], and increases the antioxidant defenses in mouse tissues [31]. In addition, the treatment with captopril produces a decrease in the left ventricle inflammatory cell infiltration in angiotensin II and aldosterone-salt-induced hypertension [32].

In the present work, we explore the effect of captopril on the cardiac inflammatory process associated with arterial hypertension. In particular, we have measured arterial blood pressure, heart rate, cardiac hypertrophy, as well as plasma levels and heart mRNA expression of pro-inflammatory (IL-1 $\beta$ and IL-6) and anti-inflammatory (IL-10) cytokines in SHR, with or without a chronic administration of captopril. In addition, the mRNA expression of ACE, angiotensin II type I receptor (AT1R), p22phox subunit of NADPH oxidase, and the expression and activation of $\mathrm{NFK}_{K} \mathrm{~B}$, has also been measured in the left ventricles of these animals, in order to know the mechanism(s) involved in the anti-inflammatory effects of captopril.

\section{Methods}

\section{Animals, treatments, heart tissue sampling and} measurements in plasma

This study was conducted in accordance with the National Institutes of Health (NIH) Guide for the Care and Use of Laboratory Animals. Normotensive, male Wistar-Kyoto (WKY) and spontaneously hypertensive rats (SHR) aged 18-20 weeks were obtained from Harlan IBERICA, S.A. (Barcelona, Spain). Rats were housed at a temperature of $22-24^{\circ} \mathrm{C}$ in individual cages and freely fed a regular pellet diet. They were divided into four groups of six animals each: (1) WKY (control group), (2) SHR (untreated), (3) WKY treated with captopril (WKYCPT), and (4) SHR treated with captopril (SHRCPT). Captopril (CPT) was administered during 12 weeks as a dose of 80 $\mathrm{mg} / \mathrm{kg} /$ day dissolved in the drinking water, the concentrations being adjusted according to daily water consumption and body weight in order to ensure correct dosage. Diastolic and systolic blood pressures, as well as the heart rate, were measured after the experimental period using the non-invasive and indirect method of tail-cuff occlusion in conscious animals using a NIPREM 645 pressure recorder (Cibertec, Barcelona, Spain). Body weight was determined on the same day that blood pressure was measured. At the end of the experimental period, all animals were fasted overnight before killing. They were anesthetized with pentobarbital (50 mg/kg i.p.) and blood samples were obtained by cardiac puncture and collected into tubes containing lithium heparin. Rats were killed by decapitation, then the heart was quickly removed and washed out with ice-cold $0.9 \%$ saline solution, and the left ventricle was dissected and weighed to calculate the relative left ventricle weight/body weight (LVW/BW). Samples of the left ventricle were frozen and stored at $-70^{\circ} \mathrm{C}$ until use. To minimize diurnal variations, rats were routinely killed between 09:00 and 10:00 hours.

Plasma was separated by low-speed centrifugation at $1500 \mathrm{~g}$ and at $4^{\circ} \mathrm{C}$ for $30 \mathrm{~min}$. IL-1 $\beta$, IL- 6 and IL-10 were measured in plasma using a quantitative sandwich enzyme immunoassay (commercial ELISA kits). Rat-specific monoclonal antibodies of each cytokine were precoated onto microplates (Pierce Biotechnology, Rockford, IL).

\section{NF-KB activity}

Left ventricles from all experimental animal groups were used for determination of NF-kB activity. Nuclear extracts from left ventricles were obtained using commercially available nuclear extraction kits (Active Motif, Madrid, Spain) following the manufacturer's recommendations. P65 NF- $\mathrm{kB}$ activity was assessed with a transcription factor assay kit according to the manufacturer's instructions (TransAM NF-kB p65 kit, Active Motif, Madrid, Spain), which can measure the binding of activated p65 NF-kB to its consensus sequence attached to a microwell plate. Antibodies for the activated form of the p65 subunits of NF- $\mathrm{kB}$ were included in the assay. 


\section{Reverse transcription and real-time polymerase chain reaction (RT-PCR)}

Reverse transcription (RT) and real-time PCR was analyzed as previously reported [8]. Whole RNA was extracted from frozen left ventricle rats after homogenization with $1 \mathrm{~mL}$ of Tripure Isolation Reagent (Roche Diagnostics Corp., Indianapolis, USA) as described by Chomczynski and Sacchi [33]. RT was carried out in a final volume of $100 \mu \mathrm{L}$ using a Ready-To-Go You-Prime First-Strand Beads (GE Healthcare, Madrid, Spain) according to the supplier's protocol. After RT, cDNA was purified using a commercial kit (GFX DNA purification kit, GE Healthcare, Madrid, Spain). cDNA was then diluted in sterile water and used as template for the amplification by the polymerase chain reaction (PCR). The specific mRNA sequences were amplified using the following pairs of primers: (from 5 ' to $3^{\prime}$ ):

IL-1 $\beta$ forward: GAGG CTGACAGACCCCAAAAGAT.

IL-1 $\beta$ reverse: GCACGAGGCATTTTTGTTGTTCA (product size $336 \mathrm{bp}$ ).

IL-6 forward: GAAATACAAAGAAATGATGGATGCT.

IL-6 reverse: TTCAAGATGAGTTGGATGGTCT (310 bp).

p22phox forward: GCTCATCTGTCTGCTGGAGTA,

p22phox reverse: ACGACCTCATCTGTCACTGGA (434 bp);

ACE forward: CAAAGTTCACTTGCTTCTTGG.

ACE reverse: TACTGTAAATGGTGCTCATGG (262 bp).

AT1R forward: CACCTATGTAAGATCGCTTC.

AT1R reverse: GCACAATCGCCATAATTATCC (445 bp).

p65 NF-кB forward: CCTAGCTTTCTCTGAACTGCAAA

p65 NF-кB reverse: GGGTCAGAGGCCAATAGAGA (71 bp).

IкB forward: TGGCTCATCGTAGGGAGTTT

I $\mathrm{B}$ reverse: CTCGTCCTCGACTGAGAAGC (68 bp)

GAPDH forward: GCCAAAAGGGTCATCATCTCCGC.

GAPDH reverse: GGATGACCTGCCCACAGCCTTG (319 bp).

Each specific gene product was amplified by real-time PCR using Sybergreen TM reactions and an ABI PRISM 7000 Sequence Detection System (PE Applied Biosystems, Foster City, CA). Amplification data were collected by the sequence detector and analysed with sequence detection software. For each assay, a standard curve was constructed using increasing amounts of cDNA. In all cases, the slope of the curves indicated adequate PCR conditions (slope 3.2-3.4). The RNA concentration in each sample was determined from the threshold cycle $(\mathrm{Ct})$ values and calculated with sequence detection soft- ware supplied by the manufacturer. The quantitative fold changes in mRNA expression were determined as relative to GAPDH mRNA levels in each corresponding group and calculated using the $2^{-} \Delta \Delta \mathrm{CT}$ method.

\section{Calculations and statistical analysis}

The GraphPad Instat statistical program was used to analyze the data. All results were subjected to one-way analysis of variance (ANOVA) and represent means \pm S.E.M. of six animals per experimental group. Differences in mean values between groups were assessed by TukeyKramer's test and considered statistically different at $\mathrm{P}<$ 0.05 .

\section{Reagents}

Unless otherwise specified, all reagents were obtained from Sigma Chemical (Madrid, Spain). Primers for RTPCR analysis were synthesized by Tib Molbiol (Berlin, Germany). Captopril was obtained from Roig-Farma (Barcelona, Spain).

\section{Results \\ Body weight, left ventricle weight, blood pressure and heart rate}

No significant differences in body weights were observed among all four groups of animals at the end of the experimental period. The LVW/BW ratio (as an index of ventricular hypertrophy), as well as diastolic and systolic blood pressures and heart rate, were significantly increased in hypertensive animals (SHR) when compared with control, WKY rats. The treatment with captopril reversed these parameters back to normal values in SHR, and no effect of CPT was observed in WKY rats (Table 1).

\section{Plasma levels and cardiac mRNA expression of cytokines}

Plasma levels of IL- $1 \beta$ and IL- 6 were significantly higher in SHR when compared with control, normotensive WKY rats (54\% and $34 \%$, respectively). The treatment with captopril was able to reverse these increases, reaching values similar to those observed in WKY rats. On the other hand, plasma levels of IL-10 were diminished in hypertensive rats $(54 \%)$, this reduction being attenuated after treatment with captopril. No changes were observed between WKY and WKYCPT groups (Table 2). In addition, SHR showed a significant increase in the left ventricle mRNA expression of IL-1 $\beta$ and IL- 6 together with a reduction in IL-10 when compared with WKY $(15.1 \pm 1.3$ relative expression (RE) and $29.5 \pm 2.8 \mathrm{RE}$ for $\mathrm{WKY}$ and SHR, respectively, for IL-1 $\beta, p<0.01 ; 192 \pm 16.4$ RE and $723 \pm 85$ RE for WKY and SHR, respectively, for IL-6, p < $0.001 ; 80.5 \pm 2.1 \mathrm{RE}$ and $42.3 \pm 0.9 \mathrm{RE}$ for WKY and SHR, respectively, for IL-10, $\mathrm{p}<0.001)$. After the treatment with captopril, these changes were prevented and the mRNA expression in SHR became $13.7 \pm 2.2 \mathrm{RE}, 219 \pm 22$ 
Table 1: Final body weight, left ventricle weight/body weight ratio (LVW/BW), blood pressures, and heart rate in WKY, SHR, WKY treated with captopril (WKYCPT), and SHR treated with captopril (SHRCPT).

\begin{tabular}{|c|c|c|c|c|}
\hline Parameter & WKY & SHR & WKYCPT & SHRCPT \\
\hline Body weight (g) & $391 \pm 3$ & $396 \pm 10$ & $372 \pm 8$ & $385 \pm 16$ \\
\hline LVW/BW (mg/g) & $2.06 \pm 0.08$ & $2.68 \pm 0.04^{* * *}$ & $1.93 \pm 0.05^{\# \# \#}$ & $2.01 \pm 0.09 \# \# \#$ \\
\hline Final DBP $(\mathrm{mm} \mathrm{Hg})$ & $114 \pm 1$ & $207 \pm 0.6^{* * *}$ & $115 \pm 1$ \#\#\# & $117 \pm 0.7 \# \# \#$ \\
\hline Final SBP $(\mathrm{mm} \mathrm{Hg})$ & $140 \pm 0.9$ & $231 \pm 0.8^{* * *}$ & $139 \pm 1.1 \# \# \#$ & $138 \pm 0.8 \# \#$ \\
\hline Heart rate (beats/min) & $342 \pm 1.1$ & $392 \pm 2.6^{* * *}$ & $339 \pm 1.8^{\# \# \#}$ & $339 \pm 1.7 \# \#$ \\
\hline
\end{tabular}

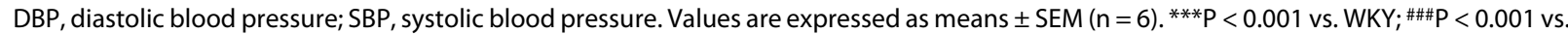
SHR.

RE and $71.2 \pm 3.3$ RE for IL-1 $\beta$, IL-6 and IL-10, respectively. In contrast, no changes were observed in the expression of these cytokines in WKY rats treated with captopril (Figure 1).

\section{Expression of ACE, AT1 receptor (AT1R) and p22phox in the heart}

Figure 2 shows ACE, AT1R and p22phox mRNA expressions in left ventricles from all groups of rats. The expression of these tree molecules was significantly increased in SHR over control, WKY rats $(13.6 \pm 0.4 \mathrm{RE}$ and $21.9 \pm 1.6$ RE for WKY and SHR, respectively, for ACE, $\mathrm{p}<0.01 ; 1.3$ $\pm 0.1 \mathrm{RE}$ and $4.3 \pm 0.6 \mathrm{RE}$ for WKY and SHR, respectively, for AT1R, p $<0.001 ; 311 \pm 16 \mathrm{RE}$ and $618 \pm 58 \mathrm{RE}$ for WKY and SHR, respectively, for $\mathrm{p} 22 \mathrm{phox}, \mathrm{p}<0.001)$. The administration of captopril to hypertensive rats was able to prevent the abnormally high values for these parameters and maintained their expressions at levels similar to those from the control group (10.9 $\pm 1 \mathrm{RE}, 2.2 \pm 0.3 \mathrm{RE}$ and $403 \pm 18$ RE for ACE, AT1R and p22phox, respectively). No effects were observed in WKY rats treated with captopril.

\section{Heart mRNA expression of the system NF-KB/IкB}

SHR showed a significant increase in the expression of NF- $\mathrm{kB}$ when compared with WKY rats $(21.8 \pm 2.5 \mathrm{RE}$ and $68.5 \pm 7.5$ RE for WKY and SHR, respectively, $\mathrm{p}<0.001$ ), and captopril prevented this alteration $(29.5 \pm 2.4 \mathrm{RE}$ for SHR treated with captopril). On the other hand, when mRNA expression of I $\beta B$ was determined, a significant decrease was observed in hypertensive animals (45.5 \pm 1.7 RE and $19.5 \pm 1.5 \mathrm{RE}$, for WKY and SHR, respectively, $\mathrm{p}<0.001$ ), and the treatment of captopril was also able to inhibit this observation $(50.0 \pm 2.2 \mathrm{RE}$ for SHR treated with captopril). Once again, no differences were observed between captopril-treated or untreated WKY rats (Figure $3)$.

\section{NF- $\mathrm{kB}$ activation}

We further investigated the effect of captopril on cardiac NF- $\kappa B$ activation. We found a $49 \%$ increase in left ventricle NF- $\mathrm{KB}$ p65 binding activity in SHR compared with WKY rats $(0.79 \pm 0.06$ optical density (OD) and $1.18 \pm$ 0.11 OD for WKY and SHR, respectively, $\mathrm{p}<0.001$ ). This activation was significantly inhibited in SHR treated with captopril $(0.61 \pm 0.05$ OD for SHR treated with captopril). No changes were observed between WKY and WKY treated with captopril (Figure 4).

\section{Discussion}

The aim of the present work was to explore the effect of captopril, a known ACE inhibitor, on the cardiovascular inflammatory process associated with arterial hypertension. In the current study we demonstrate, for the first time, that treatment with captopril reverses the observed increase in the gene expression of pro-inflammatory cytokines (IL-1 $\beta$ and IL-6), and the decrease in the gene expression of anti-inflammatory cytokines (IL-10), in the left ventricle of SHR; this effect is mediated by an inacti-

Table 2: Plasma levels of interleukin-1 $\beta$ (IL-1 $\beta$ ), interleukin-6 (IL-6) and interleukin-10 (IL-10) in WKY, SHR, WKY treated with captopril (WKYCPT), and SHR treated with captopril (SHRCPT).

\begin{tabular}{lcccc}
\hline Parameter & WKY & SHR & WKYCPT & SHRCPT \\
\hline $\mathrm{IL}-1 \beta(\mathrm{pg} / \mathrm{mL})$ & $19.8 \pm 1.2$ & $32.3 \pm 1.7^{* * *}$ & $19.7 \pm 0.8^{\# \# \#}$ & $20.7 \pm 1.8^{\# \# \#}$ \\
$\mathrm{IL}-6(\mathrm{pg} / \mathrm{mL})$ & $81.7 \pm 1$ & $112.4 \pm 7^{* *}$ & $65.7 \pm 1.6^{\# \# \#}$ & $77 \pm 6.5^{\# \# \#}$ \\
$\mathrm{IL}-10(\mathrm{pg} / \mathrm{mL})$ & $57.5 \pm 2.3$ & $26.2 \pm 0.9^{* * *}$ & $49.3 \pm 1.7^{\# \# \#}$ & $45 \pm 3.3^{* *, \# \# \#}$ \\
\hline
\end{tabular}

Values are expressed as means \pm SEM $(n=6) .{ }^{* * P}<0.01,{ }^{* * * P}<0.001$ vs. WKY; \#\#\#P<0.001 vs. SHR. 


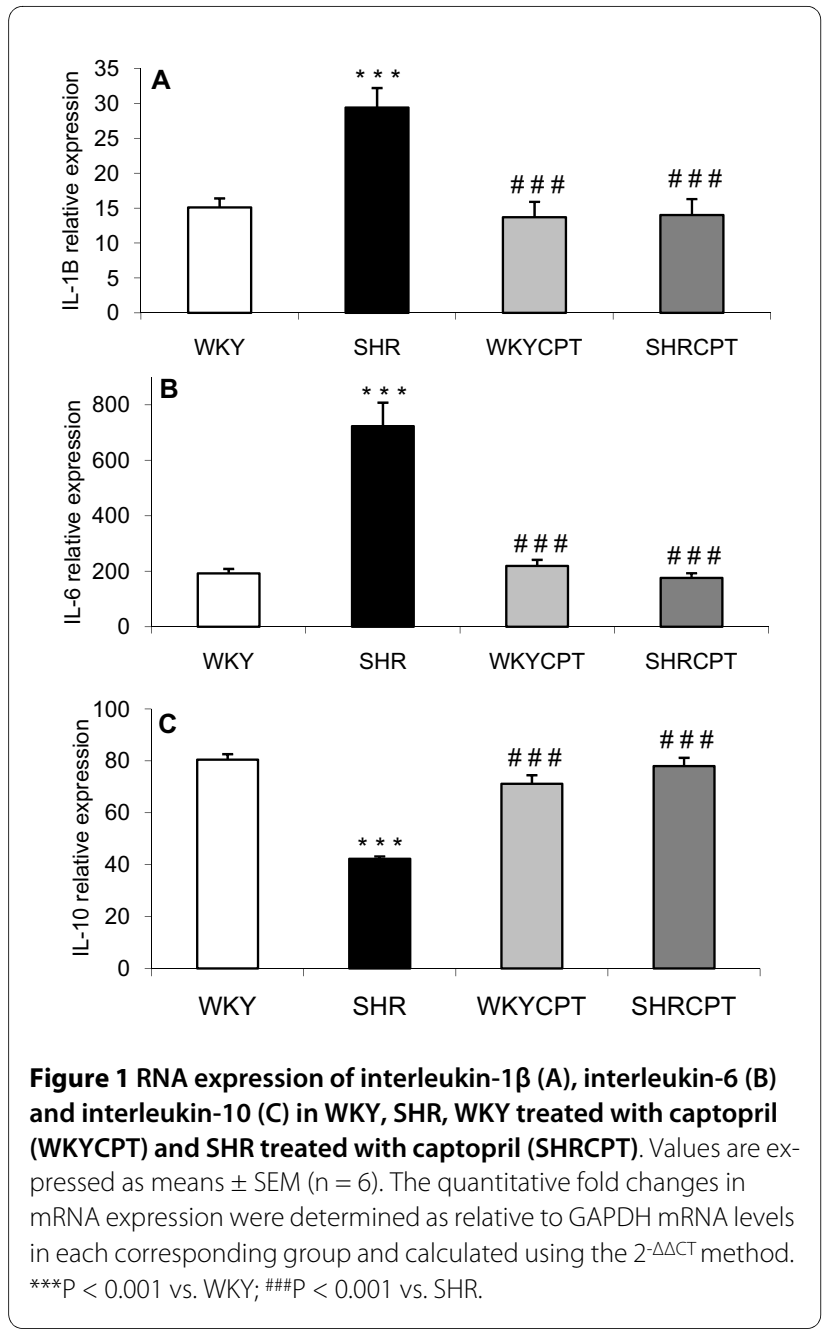

vation of RAS that in turn produces an inhibition of $\mathrm{NADPH}$ oxidase and a reduced activation of NF- $\mathrm{kB}$.

At the end of the treatment period, we observed an increase in blood pressures and in the heart rate in SHR when compared with WKY rats, as expected from previous observations [34-37]. The high levels of blood pressure and heart rate were accompanied by increases in the relative left ventricle weight and in plasma levels of both IL- $1 \beta$ and IL- 6 , and also by a reduction in the plasma levels of IL-10. An increase in circulating pro-inflammatory markers has been found in hypertensive patients [38] and in patients with pulmonary arterial hypertension [39], as well as in SHR [40], and in NO-deficient rats [8]. In contrast, a decrease in plasma levels of IL-10 has been found in patients with coronary artery disease and arterial hypertension [41], and in patients with pulmonary arterial hypertension [39]. In addition, IL-10 prevented the development of monocrotaline-induced pulmonary arterial hypertension in rats [42]. The observed changes in plasma levels of inflammatory markers in SHR were also accompanied by similar alterations in the left ventricle

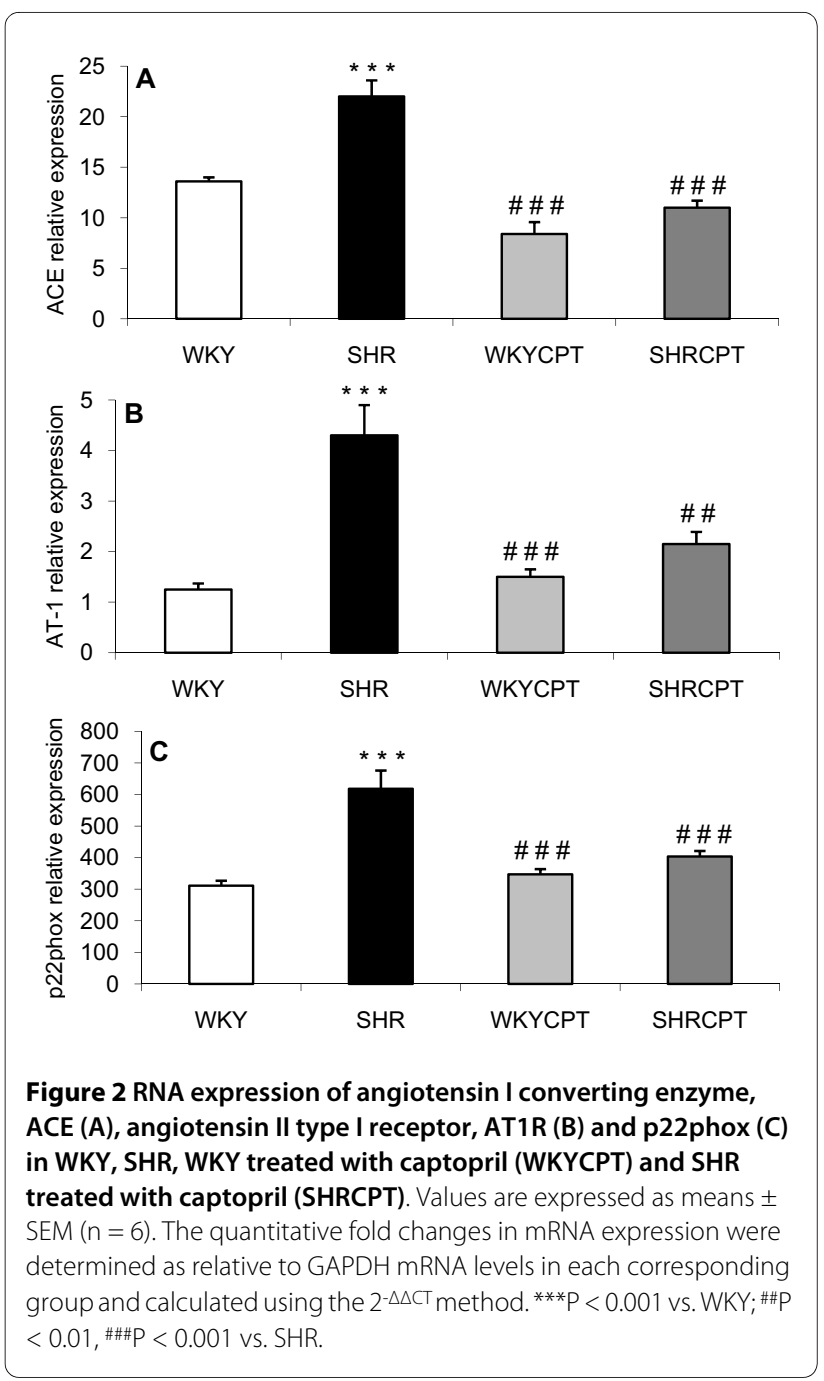

mRNA expression of these cytokines. These results are in agreement with previous studies showing that cardiac hypertrophy is associated with an inflammatory process in the myocardium of SHR $[7,16]$ and other models of hypertension rats $[8,17]$. Moreover, the mRNA expression of IL-1 $\beta$ and IL-6 [40], intercellular/vascular cell adhesion molecules (ICAM, VCAM) and monocyte chemoattractant protein (MCP-1), have been reported to be enhanced in aortas of hypertensive rats $[18,40]$, and in cardiac tissue from different rat models of hypertension $[5,43]$. However, to our knowledge, this is the first evidence concerning the decrease in plasma levels and left ventricle mRNA expression of IL-10 in hypertensive animals. Previous work has proven that endogenous IL-10 limits angiotensin II (ANG II)-mediated oxidative stress, inflammation and vascular dysfunction both in vivo and in vitro, suggesting a protective action of IL-10 in vascular diseases such as arterial hypertension [14]. In fact, IL10 attenuates the increases in vascular superoxide and endothelial dysfunction during diabetes and atheroscle- 

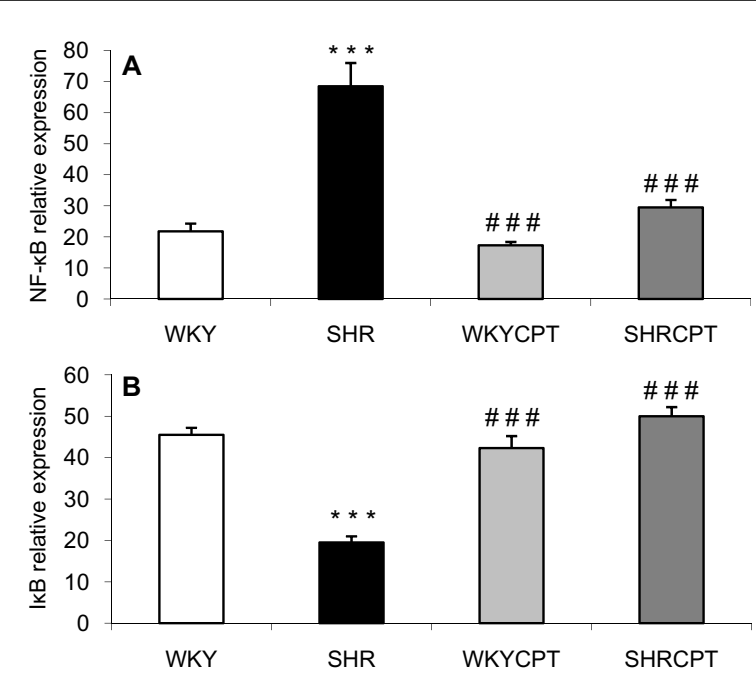

Figure 3 RNA expression of NF-KB (A) and IKB (B) in WKY, SHR, WKY treated with captopril (WKYCPT) and SHR treated with captopril (SHRCPT). Values are expressed as means $\pm \operatorname{SEM}(n=6)$. The quantitative fold changes in $\mathrm{mRNA}$ expression were determined as relative to GAPDH mRNA levels in each corresponding group and calculated using the $2-\Delta \Delta C T$ method. ${ }^{* *} P<0.001$ vs. WKY; $\# \# \# P<0.001$ vs. SHR.

rosis $[44,45]$. In the same way, it could be suggested that IL-10 might be a mediator of cardiac protection against arterial hypertension.

The administration of captopril was able to prevent the increase in blood pressures and heart rate observed in SHR and reversed the enhancement in the left ventricle weight index completely. These results are in agreement with previous studies using SHR [16,46], NO-deficient hypertensive rats [47] and obese Zucker rats, a model of non-insulin-dependent diabetic hypertensive rats [48]. In addition, when captopril was chronically administered, the observed alterations in hypertensive animals regarding plasma levels and left ventricle mRNA expression of

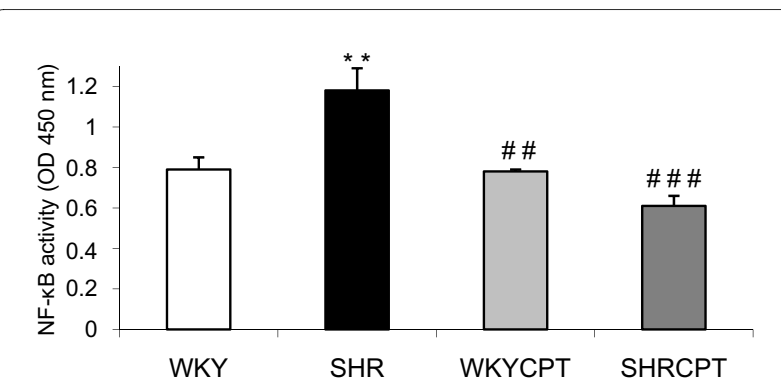

Figure 4 Nuclear factor-kappa (NF-KB) activity in nuclear extract of the left ventricle in WKY, SHR, WKY treated with captopril (WKYCPT) and SHR treated with captopril (SHRCPT). Values are expressed as means \pm SEM $(n=6) .{ }^{* *} P<0.01$ vs. WKY; \#\# $<0.01$, \#\#P $<$ 0.001 vs. SHR. inflammatory cytokines disappeared, the values reaching levels similar to those observed in WKY rats. In a previous work, enalapril (another ACE inhibitor) was able to produce an increase in plasma levels of IL-10 in patients with coronary artery disease and arterial hypertension[41]. Therefore, these results suggest an anti-inflammatory, cardioprotective effect of captopril in arterial hypertension, with a reduction in the circulating proinflammatory markers and an increase in those antiinflammatory cytokines; these effects result in a benefit on the myocardial inflammatory process associated to arterial hypertension.

This anti-inflammatory effect of captopril has been previously proved in other diseases characterized by an increase in the inflammation process, such as nephropathy [26], arthritis [27], colitis [28] and uveitis [29]. Moreover, captopril produced a reduction in the inflammatory cell infiltration in the left ventricle of rats with angiotensin II and aldosterone-salt-induced hypertension $[23,32]$.

Since several studies have shown the role of ANGII in the beneficial effect of captopril in arterial hypertension $[30,49]$, more studies were designed in order to understand the mechanisms involved in the anti-inflammatory properties of captopril in the left ventricle of SHR. Our results indicate that captopril might act via interfering with NF-kB pathway activation, most probably by blocking the ANGII II production in the left ventricle of hypertensive animals. We found that captopril was able to prevent the increase in the left ventricle expression of ACE and AT1R observed in SHR, leading to a decrease in the local production and effect of ANGII. Bolterman et al. [34] previously observed an increase in ANGII levels in plasma of SHR when compared with WKY rats, which was corrected after the treatment with captopril. In addition, a specific down-regulation of ACE and AT1R by captopril has been also demonstrated in human dendritic cells [50] and in aorta and heart tissue of fructose-fed rats [51], respectively.

ANGII stimulates various signalling pathways that lead to NF-kB activation [11,52]. Thus, ANGII stimulates NADPH oxidase, which generates reactive oxygen species (ROS), and ROS are involved as second messengers in NF- $\kappa B$ activation and cytokine expression [53]. NF- $\kappa B$ plays a crucial role regulating at the transcriptional level several pro-inflammatory genes [6]. ANGII influences $\mathrm{NF}-\mathrm{\kappa B}$ activation by stimulating the nuclear translocation of the p65 subunit, DNA binding, transcription of a NF$\kappa B$ reporter gene and I- $\mathrm{\kappa B}$ degradation. Conversely, NF$\kappa \mathrm{B}$ stimulates the expression of the gene encoding angiotensinogen, thereby amplifying the ANGII-mediated inflammatory process [54]. On the other hand, it has been reported that a major role for IL-10 is to inhibit the 
expression of pro-inflammatory cytokines, such as IL-6, through an inactivation of NF-KB [55].

Numerous studies have shown that NF-kB participates in the vascular, renal and cardiac inflammatory processes in different models of arterial hypertension through its ability to activate a variety of inflammation-mediating genes. In experimental models of hypertension, the inhibition of NF-kB prevented ANGII-induced expression of IL-6, VCAM-1 and MCP-1, thus attenuating the inflammatory damage caused by ANGII [56,57].

The present study shows that the increase in the mRNA expression of IL-1 $\beta$ and IL- 6 and the decrease in the mRNA expression of IL-10 in SHR is associated with an abnormally high cardiac mRNA expression of both p22phox (subunit of NADPH oxidase) and NF-kB, and a lower expression of $\mathrm{I} \kappa \mathrm{B}$ (a molecule that inhibits the translocation of NF- $\mathrm{kB}$ to the nucleus and its subsequent activation). In addition, a higher activation of NF- $\mathrm{kB}$ has been found in the left ventricle of hypertensive animals when compared with WKY rats. These results are in agreement with previous studies that reported an increase in NF- $\mathrm{KB}$ expression in SHR aorta and left ventricle $[40,56]$, and also in the renal activation of NF- $\mathrm{KB}$ in SHR and in salt-sensitive hypertension $[4,58]$.

When captopril was administered to hypertensive rats, the decrease in mRNA expression of pro-inflammatory markers and the increase in the expression of anti-inflammatory cytokine were accompanied by a reduction in the gene expression of p22phox and NF- $\mathrm{kB}$, and by an increase in that of IкB. Moreover, captopril was able to reverse the activation of NF- $\mathrm{kB}$ found in left ventricle of SHR. These results suggest an inactivation of the NF- $\mathrm{kB}$ system in the beneficial effect of captopril in hypertension-induced cardiac damage. A decrease in the gene expression of NF- $\mathrm{KB}$ has been observed in aortas of SHR treated with the AT1R blocker, candesartan [59], and inactivation of NF-kB has been found in aortas of rats infused with ANGII and then treated with losartan [60]; in macrophages and vascular smooth muscle cells from a rabbit model of atherosclerosis after the treatment with quinapril [19]; in the kidney cortex of rats with unilateral urethral obstruction treated with enalapril [61], and in captopril-treated uveitis [29]. In contrast, no changes in the protein expression of NF- $\mathrm{kB}$ was reported in the left ventricle of captopril-treated SHR[4].

It has been proposed that an increased superoxide production contributes to the development of hypertension via activation of the sympathetic nervous system [62]. The presence of changes in heart rate in captopril-treated rats suggests that the effect of sympathetic function might play a major role in the antihypertensive effect of this compound. Moreover, the anti-inflammatory effect of captopril occurred together with a decrease in blood pressure. It has been demonstrated that mechanical stress induces reactive oxygen species formation via an up-regulation of NADPH oxidase $[4,62]$. Therefore, the observed anti-inflammatory and cardiac effects of captopril in SHR might be due not only to the inactivation of RAS above mentioned, but also to a reduction of the mechanical stress on the vessel wall.

\section{Conclusions}

Our findings show that captopril decreases the inflammation process in the left ventricle of hypertensive rats through a reduction in the activation of NF-kB-dependent pro-inflammatory factors. Since the anti-inflammatory effect of captopril occurred together with a reduction in blood pressure and heart rate, it is possible that a part of the observed anti-inflammatory and cardioprotective effects of captopril might be due to the reduction in mechanical stress on the wall. Thus, it could be proposed that both the inactivation of RAS and blood pressure reduction are mechanisms accounting for the anti-inflammatory effect of captopril in SHR.

\section{Abbreviations}

ACE: angiotensin converting enzyme; IL-1ß: interleukin-1 $\beta$; IL-6: interleukin-6; SHR: spontaneously hypertensive rats; WKY: Wistar Kyoto rats; AT-1R: angiotensin II type I receptor; ANG II: angiotensin II; RAS: renin-angiotensin system; NF-kB: nuclear factor KB; I-KB: nuclear factor KB inhibitor; NO: nitric oxide; ICAM1: intercellular adhesion molecule-1; CPT: captopril; RT-PCR: reverse transcription and real time polymerase chain reaction; GAPDH: glyceraldehyde 3-phosphate dehydrogenase; NADPH: nicotinamide adenine dinucleotide phosphate.

\section{Competing interests}

The authors declare that they have no competing interests.

\section{Authors' contributions}

The manuscript was written and experiments designed by AM and CMV. All experiments were performed by JLMC, SZ and AJB, and supervised by $A M$ and CMV. All authors have given final approval of the version to be published.

\section{Acknowledgements}

This work was supported by a grant from Ministerio de Sanidad y Consumo, Instituto de Salud Carlos III, Fondo de Investigación Sanitaria (PI051026) and Consejería de Salud, Junta de Andalucía (PI-0034). The group is member of the Network for Cooperative Research on Membrane Transport Proteins (REIT), cofunded by the Ministerio de Educación y Ciencia, Spain and the European Regional Development Fund (ERDF) (Grant BFU2007-30688-E/BFI). S. Zambrano, JL Miguel-Carrasco and A. Blanco were supported by grants from Consejería de Salud, Junta de Andalucía (PI-0034) and Ministerio de Sanidad y Consumo, Instituto de Salud Carlos III, Fondo de Investigación Sanitaria (PS09/ 01395).

\section{Author Details}

Departamento de Fisiología y Zoología, Facultad de Farmacia, Universidad de Sevilla, E-41012 Sevilla, Spain

Received: 6 October 2009 Accepted: 12 May 2010

Published: 12 May 2010

\section{References}

1. Bell D, Kelso EJ, Argent CC, Lee GR, Allen AR, McDermott BJ: Temporal characteristics of cardiomyocyte hypertrophy in the spontaneously hypertensive rat. Cardiovasc Pathol 2004, 13:71-78.

2. Brooksby P, Levi AJ, Jones JV: The electrophysiological characteristics of hypertrophied ventricular myocytes from the spontaneously hypertensive rat. J Hypertens 1993, 11:611-622. 
3. Matsuoka H, Nakata M, Kohno K, Koga Y, Nomura G, Toshima H, Imaizumi $\mathrm{T}$ : Chronic L-arginine administration attenuates cardiac hypertrophy in spontaneously hypertensive rats. Hypertension 1996, 27:14-18.

4. Simko F, Pechanova O, Pelouch V, Krajcirovicova K, Mullerova M, Bednarova K, Adamcova M, Paulis L: Effect of melatonin, captopril, spironolactone and simvastatin on blood pressure and left ventricular remodelling in spontaneously hypertensive rats. J Hypertens 2009, 27(Suppl 6):S5-10.

5. Luft FC, Mervaala E, Muller DN, Gross V, Schmidt F, Park JK, Schmitz C, Lippoldt A, Breu V, Dechend R, Dragun D, Schneider W, Ganten D, Haller $\mathrm{H}$ : Hypertension-induced end-organ damage: A new transgenic approach to an old problem. Hypertension 1999, 33:212-218.

6. Savoia C, Schiffrin EL: Inflammation in hypertension. Curr Opin Nephrol Hypertens 2006, 15:152-158.

7. Sun L, Gao YH, Tian DK, Zheng JP, Zhu CY, Ke Y, Bian K: Inflammation of different tissues in spontaneously hypertensive rats. Sheng Li Xue Bao 2006, 58:318-323.

8. Miguel-Carrasco JL, Mate A, Monserrat MT, Arias JL, Aramburu O, Vazquez CM: The role of inflammatory markers in the cardioprotective effect of L-carnitine in L-NAME-induced hypertension. Am J Hypertens 2008, 21:1231-1237.

9. Sharma U, Rhaleb NE, Pokharel S, Harding P, Rasoul S, Peng H, Carretero OA: Novel anti-inflammatory mechanisms of N-Acetyl-Ser-Asp-Lys-Pro in hypertension-induced target organ damage. Am J Physiol Heart Circ Physiol 2008, 294:H1226-H1232.

10. Sun Y, Ratajska A, Zhou G, Weber KT: Angiotensin-converting enzyme and myocardial fibrosis in the rat receiving angiotensin II or aldosterone. J Lab Clin Med 1993, 122:395-403.

11. Brasier AR, Jamaluddin M, Han Y, Patterson C, Runge MS: Angiotensin II induces gene transcription through cell-type-dependent effects on the nuclear factor-kappaB (NF-kappaB) transcription factor. Mol Cell Biochem 2000, 212:155-169.

12. Hall G, Hasday JD, Rogers TB: Regulating the regulator: NF-kappaB signaling in heart. J Mol Cell Cardiol 2006, 41:580-591.

13. Takemoto M, Egashira K, Tomita H, Usui M, Okamoto H, Kitabatake A, Shimokawa H, Sueishi K, Takeshita A: Chronic angiotensin-converting enzyme inhibition and angiotensin II type 1 receptor blockade: effects on cardiovascular remodeling in rats induced by the long-term blockade of nitric oxide synthesis. Hypertension 1997, 30:1621-1627.

14. Didion SP, Kinzenbaw DA, Schrader LI, Chu Y, Faraci FM: Endogenous interleukin-10 inhibits angiotensin II-induced vascular dysfunction. Hypertension 2009, 54:619-624.

15. Ciulla MM, Paliotti R, Esposito A, Cuspidi C, Muiesan ML, Rosei EA, Magrini $\mathrm{F}$, Zanchetti A: Effects of antihypertensive treatment on ultrasound measures of myocardial fibrosis in hypertensive patients with left ventricular hypertrophy: results of a randomized trial comparing the angiotensin receptor antagonist, candesartan and the angiotensinconverting enzyme inhibitor, enalapril. J Hypertens 2009, 27:626-632.

16. Vapaatalo $H$, Mervaala $E$, Nurminen ML: Role of endothelium and nitric oxide in experimental hypertension. Physiol Res 2000, 49:1-10.

17. Pechanova O, Bernatova I, Pelouch V, Simko F: Protein remodelling of the heart in NO-deficient hypertension: the effect of captopril. J Mol Cell Cardiol 1997, 29:3365-3374.

18. Gonzalez W, Fontaine V, Pueyo ME, Laquay N, Messika-Zeitoun D, Philippe M, Arnal JF, Jacob MP, Michel JB: Molecular plasticity of vascular wall during $N(G)$-nitro-L-arginine methyl ester-induced hypertension: modulation of proinflammatory signals. Hypertension 2000, 36:103-109.

19. Hernandez-Presa MA, Bustos C, Ortego M, Tunon J, Ortega L, Egido J: ACE inhibitor quinapril reduces the arterial expression of NF-kappaBdependent proinflammatory factors but not of collagen I in a rabbit model of atherosclerosis. Am J Pathol 1998, 153:1825-1837.

20. Rosei EA, Rizzoni D, Muiesan ML, Sleiman I, Salvetti M, Monteduro C, Porteri E: Effects of candesartan cilexetil and enalapril on inflammatory markers of atherosclerosis in hypertensive patients with non-insulindependent diabetes mellitus. J Hypertens 2005, 23:435-444.

21. Shimozawa M, Naito Y, Manabe H, Uchiyama K, Katada K, Kuroda M, Nakabe N, Yoshida N, Yoshikawa T: The inhibitory effect of alacepril, an angiotensin-converting enzyme inhibitor, on endothelial inflammatory response induced by oxysterol and TNF-alpha. Redox Rep 2004, 9:354-359

22. Brooks WW, Bing OH, Robinson KG, Slawsky MT, Chaletsky DM, Conrad $\mathrm{CH}$ : Effect of angiotensin-converting enzyme inhibition on myocardial fibrosis and function in hypertrophied and failing myocardium from the spontaneously hypertensive rat. Circulation 1997, 96:4002-4010.

23. Peng H, Carretero OA, Vuljaj N, Liao TD, Motivala A, Peterson EL, Rhaleb NE: Angiotensin-converting enzyme inhibitors: a new mechanism of action. Circulation 2005, 112:2436-2445.

24. Albuquerque D, Nihei J, Cardillo F, Singh R: The ACE inhibitors enalapril and captopril modulate cytokine responses in Balb/c and C57Bl/6 normal mice and increase CD4(+)CD103(+)CD25(negative) splenic T cell numbers. Cell Immunol 2010, 260:92-97.

25. Constantinescu CS, Ventura E, Hilliard B, Rostami A: Effects of the angiotensin converting enzyme inhibitor captopril on experimental autoimmune encephalomyelitis. Immunopharmacol Immunotoxicol 1995, 17:471-491.

26. Tang SC, Leung JC, Chan LY, Eddy AA, Lai KN: Angiotensin converting enzyme inhibitor but not angiotensin receptor blockade or statin ameliorates murine adriamycin nephropathy. Kidney Int 2008, 73:288-299

27. Agha AM, Mansour M: Effects of captopril on interleukin-6, leukotriene $B(4)$, and oxidative stress markers in serum and inflammatory exudate of arthritic rats: evidence of antiinflammatory activity. Toxicol Appl Pharmacol 2000, 168:123-130

28. Jahovic N, Ercan F, Gedik N, Yuksel M, Sener G, Alican I: The effect of angiotensin-converting enzyme inhibitors on experimental colitis in rats. Regul Pept 2005, 130:67-74

29. Ilieva I, Ohgami K, Jin XH, Suzuki Y, Shiratori K, Yoshida K, Kase S, Ohno S: Captopril suppresses inflammation in endotoxin-induced uveitis in rats. Exp Eye Res 2006, 83:651-657.

30. Pechanova O, Matuskova J, Capikova D, Jendekova L, Paulis L, Simko F: Effect of spironolactone and captopril on nitric oxide and $S$ nitrosothiol formation in kidney of L-NAME-treated rats. Kidney Int 2006, 70:170-176

31. de Cavanagh EM, Inserra F, Ferder L, Fraga CG: Enalapril and captopril enhance glutathione-dependent antioxidant defenses in mouse tissues. Am J Physiol Regul Integr Comp Physiol 2000, 278:R572-R577.

32. Peng H, Carretero OA, Liao TD, Peterson EL, Rhaleb NE: Role of N-acetylseryl-aspartyl-lysyl-proline in the antifibrotic and anti-inflammatory effects of the angiotensin-converting enzyme inhibitor captopril in hypertension. Hypertension 2007, 49:695-703.

33. Chomczynski P, Sacchi N: The single-step method of RNA isolation by acid guanidinium thiocyanate-phenol-chloroform extraction: twentysomething years on. Nat Protoc 2006, 1:581-585.

34. Bolterman RJ, Manriquez MC, Ortiz Ruiz MC, Juncos LA, Romero JC: Effects of captopril on the renin angiotensin system, oxidative stress, and endothelin in normal and hypertensive rats. Hypertension 2005 46:943-947.

35. Mate A, Barfull A, Hermosa AM, Gomez-Amores L, Vazquez CM, Planas JM: Regulation of sodium-glucose cotransporter SGLT1 in the intestine of hypertensive rats. Am J Physiol Regul Integr Comp Physiol 2006, 291:R760-R767.

36. Miguel-Carrasco JL, Monserrat MT, Mate A, Vazquez CM: Comparative effects of captopril and I-carnitine on blood pressure and antioxidant enzyme gene expression in the heart of spontaneously hypertensive rats. Eur J Pharmacol 2010, 632:65-72.

37. Romero M, Jimenez R, Hurtado B, Moreno JM, Rodriguez-Gomez I, LopezSepulveda R, Zarzuelo A, Perez-Vizcaino F, Tamargo J, Vargas F, Duarte J: Lack of beneficial metabolic effects of quercetin in adult spontaneously hypertensive rats. Eur J Pharmacol 2010, 627:242-250

38. Peeters AC, Netea MG, Janssen MC, Kullberg BJ, Meer JW Van der, Thien T: Pro-inflammatory cytokines in patients with essential hypertension. Eur J Clin Invest 2001, 31:31-36.

39. Lei Y, Zhen J, Ming XL, Jian HK: Induction of higher expression of IL-beta and TNF-alpha, lower expression of IL-10 and cyclic guanosine monophosphate by pulmonary arterial hypertension following cardiopulmonary bypass. Asian J Surg 2002, 25:203-208.

40. Sanz-Rosa D, Oubina MP, Cediel E, de Las HN, Vegazo O, Jimenez J, Lahera V. Cachofeiro V: Effect of AT1 receptor antagonism on vascular and circulating inflammatory mediators in SHR: role of NF-kappaB/lkappaB system. Am J Physiol Heart Circ Physiol 2005, 288:H111-H115.

41. Schieffer B, Bunte C, Witte J, Hoeper K, Boger RH, Schwedhelm E, Drexler $\mathrm{H}$ : Comparative effects of AT1-antagonism and angiotensin-converting enzyme inhibition on markers of inflammation and platelet 
aggregation in patients with coronary artery disease. J Am Coll Cardiol 2004, 44:362-368.

42. Ito T, Okada T, Miyashita H, Nomoto T, Nonaka-Sarukawa M, Uchibori R, Maeda Y, Urabe M, Mizukami H, Kume A, Takahashi M, Ikeda U, Shimada K, Ozawa K: Interleukin-10 expression mediated by an adeno-associated virus vector prevents monocrotaline-induced pulmonary arterial hypertension in rats. Circ Res 2007, 101:734-741.

43. Koyanagi M, Egashira K, Kitamoto S, Ni W, Shimokawa H, Takeya M, Yoshimura T, Takeshita A: Role of monocyte chemoattractant protein-1 in cardiovascular remodeling induced by chronic blockade of nitric oxide synthesis. Circulation 2000, 102:2243-2248.

44. Gunnett CA, Heistad DD, Faraci FM: Interleukin-10 protects nitric oxidedependent relaxation during diabetes: role of superoxide. Diabetes 2002, 51:1931-1937.

45. Mallat Z, Besnard S, Duriez M, Deleuze V, Emmanuel F, Bureau MF, Soubrier F, Esposito B, Duez H, Fievet C, Staels B, Duverger N, Scherman D, Tedgui A: Protective role of interleukin-10 in atherosclerosis. Circ Res 1999, 85:e17-e24

46. Vrankova S, Jendekova L, Paulis L, Sladkova M, Simko F, Pechanova O: Comparison of the effects of indapamide and captopril on the development of spontaneous hypertension. J Hypertens 2009, 27(Suppl 6):S42-6. S42-S46

47. Bernatova I, Pechanova O, Pelouch V, Simko F: Regression of chronic LNAME-treatment-induced left ventricular hypertrophy: effect of captopril. J Mol Cell Cardiol 2000, 32:177-185.

48. Bernatova I, Pechanova O, Simko F: Effect of captopril in L-NAMEinduced hypertension on the rat myocardium, aorta, brain and kidney. Exp Physiol 1999, 84:1095-1105.

49. Diep QN, El MM, Cohn JS, Endemann D, Amiri F, Virdis A, Neves MF, Schiffrin EL: Structure, endothelial function, cell growth, and inflammation in blood vessels of angiotensin II-infused rats: role of peroxisome proliferator-activated receptor-gamma. Circulation 2002, 105:2296-2302

50. Lapteva N, Ide K, Nieda M, Ando Y, Hatta-Ohashi Y, Minami M, Dymshits G, Egawa K, Juji T, Tokunaga K: Activation and suppression of reninangiotensin system in human dendritic cells. Biochem Biophys Res Commun 2002, 296:194-200.

51. Nyby MD, Abedi K, Smutko V, Eslami P, Tuck ML: Vascular Angiotensin type 1 receptor expression is associated with vascular dysfunction, oxidative stress and inflammation in fructose-fed rats. Hypertens Res 2007, 30:451-457.

52. Kranzhofer R, Browatzki M, Schmidt J, Kubler W: Angiotensin II activates the proinflammatory transcription factor nuclear factor-kappaB in human monocytes. Biochem Biophys Res Commun 1999, 257:826-828.

53. Saito Y, Berk BC: Angiotensin II-mediated signal transduction pathways. Curr Hypertens Rep 2002, 4:167-171.

54. Costanzo A, Moretti F, Burgio VL, Bravi C, Guido F, Levrero M, Puri PL: Endothelial activation by angiotensin II through NFkappaB and p38 pathways: Involvement of NFkappaB-inducible kinase (NIK), free oxygen radicals, and selective inhibition by aspirin. J Cell Physio/ 2003 , 195:402-410.

55. Savoia C, Schiffrin EL: Vascular inflammation in hypertension and diabetes: molecular mechanisms and therapeutic interventions. Clin Sci (Lond) 2007, 112:375-384

56. Jiang B, Xu S, Hou X, Pimentel DR, Cohen RA: Angiotensin II differentially regulates interleukin-1-beta-inducible NO synthase (iNOS) and vascular cell adhesion molecule-1 (VCAM-1) expression: role of p38 MAPK. J Biol Chem 2004, 279:20363-20368

57. Muller DN, Dechend R, Mervaala EM, Park JK, Schmidt F, Fiebeler A, Theuer J, Breu V, Ganten D, Haller H, Luft FC: NF-kappaB inhibition ameliorates angiotensin II-induced inflammatory damage in rats. Hypertension 2000, 35:193-201.

58. Gu JW, Tian N, Shparago M, Tan W, Bailey AP, Manning RD Jr: Renal NFkappaB activation and TNF-alpha upregulation correlate with saltsensitive hypertension in Dahl salt-sensitive rats. Am J Physiol Regul Integr Comp Physiol 2006, 291:R1817-R1824.

59. Sanz-Rosa D, Oubina MP, Cediel E, de Las HN, Vegazo O, Jimenez J, Lahera V, Cachofeiro V: Effect of AT1 receptor antagonism on vascular and circulating inflammatory mediators in SHR: role of NF-kappaB/lkappaB system. Am J Physiol Heart Circ Physiol 2005, 288:H111-H115.

60. Tummala PE, Chen XL, Sundell CL, Laursen JB, Hammes CP, Alexander RW, Harrison DG, Medford RM: Angiotensin II induces vascular cell adhesion molecule-1 expression in rat vasculature: A potential link between the renin-angiotensin system and atherosclerosis. Circulation 1999, 100:1223-1229

61. Morrissey JJ, Klahr S: Rapid communication. Enalapril decreases nuclear factor kappa B activation in the kidney with urethral obstruction. Kidney Int 1997, 52:926-933.

62. Shokoji T, Nishiyama A, Fujisawa Y, Hitomi H, Kiyomoto H, Takahashi N, Kimura S, Kohno M, Abe Y: Renal sympathetic nerve responses to tempol in spontaneously hypertensive rats. Hypertension 2003, 41:266-273.

doi: 10.1186/1476-9255-7-21

Cite this article as: Miguel-Carrasco et al., Captopril reduces cardiac inflammatory markers in spontaneously hypertensive rats by inactivation of NF-kB Journal of Inflammation 2010, 7:21

\section{Submit your next manuscript to BioMed Central and take full advantage of:}

- Convenient online submission

- Thorough peer review

- No space constraints or color figure charges

- Immediate publication on acceptance

- Inclusion in PubMed, CAS, Scopus and Google Scholar

- Research which is freely available for redistribution
C) Biomed Central 